\title{
Anatomy and micromorphometry of Caryocar brasiliense leaves
}

Caracterização anatômica e micromorfométrica em folhas de Caryocar brasiliense

\author{
Bárbara Helena Ramos ${ }^{1,4}$, Kellen Lagares Ferreira Silva ${ }^{2,4}$, Ronaldo Rodrigues Coimbra ${ }^{2,4}$, Davi Borges \\ Chagas $^{3,4}$ \& Wagner de Melo Ferreira ${ }^{2,4}$
}

\begin{abstract}
The current study aims to study the anatomy and micromorphometry of C. brasiliense leaves in three Cerrado (savanna) vegetation-types: dense, typical and sparse) - in the municipality of Porto Nacional-TO. Samples were collected, fixed and stored in alcohol $70 \%$. Transverse, longitudinal and paradermal sections of the median leaflet were prepared for anatomical and micromorphometric studies using standard techniques. C. brasiliense leaflets show uniestratified epidermis covered by thick cuticle on the adaxial surface and by paracytic stomata and multicellular non-glandular trichomes on the abaxial surface. The mesophyll is formed by two or three layers of palisade parenchyma adaxially and spongy parenchyma abaxially. The vascular bundle is of the collateral type and the accessory bundles show a sheath extending into the epidermides. The micromorphometric analyses pointed to significant differences in the thickness of both adaxial epidermis and spongy parenchyma in all specimens from the three vegetation-types. The highest averages were found in the leaflets of sparse cerrado plants, suggesting that environmental factors may have an influence over the plants morphological responses.
\end{abstract}

Key words: Caryocaraceae, Micromorphometry, Pequi, Morphology.

\section{Resumo}

O objetivo do trabalho foi caracterizar anatômica e micromorfometricamente folhas de C. brasiliense em três fitofisionomias do Cerrado (denso, típico e ralo), no município de Porto Nacional-TO. Amostras foram coletadas, fixadas e armazenadasestocadas em álcool $70 \%$. Utilizando técnicas usuais para estudos em anatomia vegetal, foram obtidas secções transversais, longitudinais e paradérmicas do folíolo mediano para estudos anatômicos e micromorfométricos. Os folíolos de C. brasiliense apresentaram epiderme uniestratificada, recoberta por cutícula espessa na face adaxial e por estômatos paracíticos e tricomas tectores pluricelulares na face abaxial. O mesofilo é formado por duas a três camadas de parênquima paliçádico na face adaxial e esponjoso na abaxial. O feixe vascular é do tipo colateral, com demais feixes acessórios apresentando bainha que se estende até a epiderme. As análises micromorfométricas revelaram diferenças significativas na espessura da epiderme adaxial e do parênquima esponjoso em todas as plantas estudadas para cada uma das três fitofisionomias, sendo as médias mais elevadas encontradas nos folíolos das plantas crescendo em Cerrado esparso. Isto sugere que a influência de fatores ambientais pode ter modulado respostas morfológicas nas plantas.

Palavras-chave: Caryocaraceae, Micromorfometria, Pequi, Morfologia.

\section{Introduction}

Cerrado is a Central Brazilian biome characterized primarily by large expanses of savanna-type grassland including variable representation of woody species including a mosaic of physiognomies or vegetation-types (Ribeiro $\&$ Walter 2008) ranging from grassland to forest formations. The typical Cerrado includes trees and

\footnotetext{
${ }^{1}$ Fundação Universidade do Tocantins (UNITINS), 108 sul, alameda 11, lote 3, plano diretor sul, 77020-122 Palmas, TO, Brazil.

${ }^{2}$ Universidade Federal do Tocantins (UFT), Curso de Ciências Biológicas, R. 7, quadra 15, s/n, Jardim dos Ipês, 77500-000, Porto Nacional, TO, Brazil.

${ }^{3}$ Universidade Federal do Tocantins (UFT), R. 7, quadra 15, s/n, Jardim dos Ipês, 77500-000, Porto Nacional, TO, Brazil.

[4Emails para correspondência: ronaldo.rc@mail.uft.edu.br, lagares@mail.uft.edu.br,wmelouft@yahoo.com, davibchagas@gmail.com,babihr@gmail.com.
} 
shrubs growing in a continuous grassy stratum, without the formation of a continuous canopy. There are four main types of vegetation-types in these formations: cerradão, cerrado strictu sensu, cerrado park, palm Grove and Palm Swamp (Ribeiro \& Walter 2008). The Cerrado strictu sensu is divided into four vegetation-types: dense, typical, sparse and rupestrian (Reatto \& Martins 2005; Ribeiro \& Walter 2008).

The State of Tocantins can be considered the core-region for this biome. Tocantins has varied geology and altitudinal ranges, and consequently diverse Cerrado vegetation-types are found there (Reatto \& Martins 2005).

Cerrado soils are generally well drained, deep, acidic, poor in nutrients and often with high concentrations of aluminum (Felfili \& Júnior Silva 2005). The climate in the Brazilian central plateau region, where Tocantins is located, is seasonal, characterized by dry winters and rainy summers, with rainfall concentrated between October and April (Franco 2005).

Caryocar brasiliense Cambess, popularly known as pequi, is a widely known and distributed species from the Cerrado, found in the Brazilian states of Tocantins, Pará, Mato Grosso, Goiás, Distrito Federal, Minas Gerais, São Paulo and Paraná. It belongs to the Caryocaraceae family, which has two genera - Caryocar L. and Anthodiscus G.F.W. Meyer - and 26 species. It is mainly found in vegetation-types such as cerradão, cerrado strictu sensu and cerrado park (Almeida et al. 1998; Almeida \& Silva 1994; Ribeiro \& Walter 2008).

Physiologic features as well as phenology, including leaf-fall, sprouting, flowering and fruiting of $C$. brasiliense may vary throughout its distribution range due to edaphoclimatic conditions, making the Cerrado a suitable environment for environmental and plant population variation studies (Rocha-Filho \& Lomônaco 2006; Araujo 1995).

Caryocar brasiliense is economically appreciated for its timber, fruits and seeds (Barradas 1972; Araujo1995). It is a tree of thick and twisted trunk and wide crown, reaching up to $10 \mathrm{~m}$ high. (Gonçalves \& Lorenzi 2007; Lorenzi \& Matos 2008). Its leaves are petiolate, trifoliolate, opposite (rarely alternate), bright-green and coriaceous. Each leaflet has penninerved venation and usually serrate, dentate or crenate margins (Prance \& Silva 2006; Lorenzi \& Matos 2008).

The study of plant diversity through plant anatomy is increasingly important in helping to understand plant ecology, physiology and morphology within a given ecosystem, and additionally may focus in applications of economic importance (Cutler et al. 2011; Rocha-Filho \& Lomônaco 2006).

Therefore, studies have used anatomical parameters such as tissue morphometry (Santos - Sant anna et al. 2007), morphoanatomy and histochemistry (Bieras \& Sajo 2004); (Lusa \& Bona 2011) as tools for studying species of plants growing in different environments.

The current study aims to investigate the anatomy and micromorphometry of $C$. brasiliense leaves in three different Cerrado vegetation-types.

\section{Materials and Methods}

The study was conducted in a natural $C$. brasiliense population located in São Judas Tadeu farm reserve area (geographic coordinates: $\mathrm{S} 10^{\circ} 48^{\prime}$ 21.64"; W $\left.48^{\circ} 26^{\prime} 14.17^{\prime \prime}\right)$, at $24 \mathrm{~km}$ from the town of Porto Nacional, Tocantins State. The study was carried out in three different Cerrado strictu sensu vegetation-types: dense, typical and sparse (Ribeiro \& Walter 2008).

Three soil samples were collected in each vegetation-types in August 2011, $20 \mathrm{~cm}$ deep, totalling three composite samples for each area. The physicochemical analyses were performed by Porto Fértil Laboratory, in Porto National-TO. Climate and rainfall data from Porto Nacional-TO were provided by the National Institute of Meteorology (INMET Instituto Nacional de Meteorologia).

The anatomical analyses (featuring and micromorphometry) performed between August and October 2011 used fully expanded leaves from the fourth node of 10 adult $C$. brasiliense plants collected from each vegetation-type, totalling three composite samples. As C. brasiliense (pequi) leaves are compound, only the median leaflet samples were used for the analyses.

Samples were fixed according to Johansen (1940) in FAA (formaldehyde, acetic acid and ethyl alcohol 50\%) kept under vacuum for 24 hours and stored in alcohol $70 \%$, for paraffin embedding and subsequent dehydration in ethyl and butyl series.

Samples were immersed in paraffin + $8 \%$ beeswax, following different cutting plane orientations (transverse, longitudinal and paradermal), and placed on a wooden support. Five blocks were made for each vegetation-type and respective cutting planes, totalling 30 blocks.

As for the anatomical description, longitudinal,

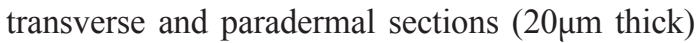


were made in manual rotary microtome (Ancap). Five slides were prepared for each block, each of them containing fifteen sections, totalling 150 slides. Subsequently, the sections were deparaffinized and stained in $1 \%$ safranin and astra blue for $20 \mathrm{~min}$, being mounted using Canada balsam.

Leaf venation structure analysis was performed by diafanization technique following Bersier \& Bocquet (1960). Samples of the median leaflet were separated into three portions: apex, middle and base. They were fixed and stored as above. The portions were stained in $1 \%$ safranin and the slides were prepared using Canada balsam.

Regarding the micromorphometric analyses, three sections were randomly marked on each slide, and only the foliar limb was photographed using 10x objective lens. Micromorphometric measurements were performed, based on these images, by means of ANATI QUANTI image analysis software, version 2.0 for Windows ${ }^{\circledR}$ (Aguiar et al. 2007). The following tissues were measured: 1) thickness of the epidermis in the adaxial and abaxial surfaces; 2) thickness of palisade and spongy parenchyma; 4) thickness of mesophyll, which was obtained by adding up the thickness of the parenchymas; 5) limb thickness, which was obtained by adding up all tissues. Three measurements were made in each tissue to obtain the average. The Kruskal-Wallis test was carried out to compare these averages, followed by Dunn's multiple comparison test at $5 \%$ significance, using Statistica 5.0 software. All observations and recordings were performed under Olympus BX 41 optical microscope with Olympus Q-Color 3 digital camera attached to it.

Dry samples of $C$. brasiliense were deposited in the herbarium of the Federal University of Tocantins (UFT) under accession number 10470.

\section{Results}

\section{Soil and climate features}

The soil analyses performed in all areas showed medium-texture soils in sparse cerrado and dense cerrado vegetation-types, whereas the soil texture of the typical cerrado was found to be sandy.

The dense cerrado vegetation-type has slightly more fertile soil than the other areas, evidenced through increased cation exchange capacity (CEC - 18.3) and higher calcium (0.82), magnesium (0.58) potassium (86.0) and phosphorus (3.5) concentrations, besides higher percentages of organic matter $(4.7 \%)$, clay (29\%) and silt (15.0\%). However, in general, the analyzed soils showed to be acidic soils with low fertility and high aluminum concentration.

As for the current study, the rainfall began in October 2010, with peak rainfall in January 2011 (353.6 mm) ceasing in May 2011 (18.8 mm). The dry season began in June and continued until September 2011, and during this period the highest temperatures were observed reaching a maximum of $38.5^{\circ} \mathrm{C}$ in September (Fig.1).

The analisis of rainfall levels (Fig.1) made it evident that the rainfall rates in the year preceding the study (2010) were lower when compared with 2011 rates.

\section{Micromorphometric analyses}

Significant differences were found in the thickness of adaxial epidermis (ADE) and spongy parenchyma (SP) in plants from all studied vegetationtypes, by comparing the micromorphometricallymeasured averages (Tab.1). However, significant differences were found in the leaflets of sparse cerrado plants only, when compared with the leaflets of plants from dense and typical cerrado vegetation-types, regarding the thickness parameters of the abaxial surface epidermis (ABE), mesophyll (MES) and limb (LIB). In opposition, regarding the palisade parenchyma tissue (PP) thickness, there was significant difference among the plants in typical cerrado vegetation-type when compared with that of dense cerrado and sparse cerrado vegetation types, which showed similar measures in this variable. It can be noticed that the higher averages were found in leaflets of sparse cerrado plants in most of the measured tissues. Only the palisade parenchyma

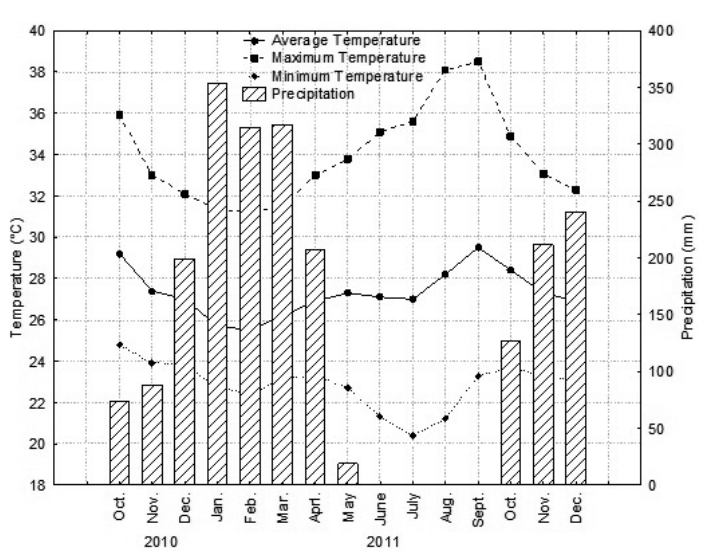

Figure 1 - Climatological data of Porto Nacional County -TO, Brazil, between October 2010 and December 2011. 
tissue (PP) showed higher value in the leaflets of plants from dense cerrado vegetation-type (Tab.1).

\section{Anatomical characteristics}

Caryocar brasiliense leaves are opposite, compound and trifoliolate. The central or median leaflet is acute to obtuse at base while the lateral leaflets have uneven base. The margins are crenate with furrowed and protruding venation (Carvalho 2009). The anatomy of $C$. brasiliense leaflets has similar features in the three studied vegetation-types. The overview of the mesophyll and the arching of the abaxial surface epidermis are acuminate or rounded in shape, as shown in figure 2a. In general, $C$. brasiliense leaflets show uniestratified epidermis with bulky and rectangular cells varying in shape and size (Fig. 2b).

The adaxial surface epidermis is more prominent, with slightly rounded and thick periclinal walls and predominantly straight anticlinal walls, with high density of simple and long multicellular non-glandular trichomes (Fig. $2 \mathrm{~b}, 2 \mathrm{c}$ and $2 \mathrm{~d}$ ).

The abaxial surface epidermis shows smaller cells with sinuous contours. Cells have many multicellular non-glandular trichomes and some unicellular, glandular ones. Both epidermal faces have thick cuticle, which is more visible in the adaxial epidermis (Fig. 2b, 2c and 2d).
The stomata are protruding and diacritictype (Fig. 2b and 2g). They are found in the abaxial surface epidermis at the same level as the other cells and show broad substomatic chamber (Fig. 2b), therefore this leaf can be considered hypostomatic.

Non-glandular, multicellular, elongated trichomes are found on the epidermal faces. They are evident and found in greater quantities around the entire midrib (Fig. 2c) and on the abaxial surface epidermis (Fig. 2d).

The mesophyll consists of palisade parenchyma facing the adaxial surface epidermis and of spongy parenchyma facing the abaxial surface epidermis (Fig. 2b). The palisade parenchyma has two or three layers of elongated and compacted cells, followed by two to three layers of spongy parenchyma with cells of varied size and shape, predominantly less rounded and less compacted, with both parenchymas showing small intercellular spaces (Fig. $2 \mathrm{~b}$ and $2 \mathrm{~d}$ ).

The vascular bundle type is collateral. The main nervure has a central vein surrounded by layers of isodiametrical parenchyma cells that are intensely stained by safranin (Fig. $2 \mathrm{e}$ and $2 \mathrm{f}$ ). It also has medium- and small-sized bundles, which sheath extends into the epidermis (Fig. 2b, 2d and $2 \mathrm{e})$. The vascular ending arrangements are characterized as branched (Fig. 2h).

Table 1 - Comparison of the mean thickness of plant tissues in the leaflets from dense, typical and sparse cerrado vegetation-types. Porto Nacional-TO, 2012.*

\begin{tabular}{lcccccc}
\hline Vegetation Types & ADE $(\mu \mathrm{m})$ & $\mathbf{A B E}(\mu \mathrm{m})$ & $\mathbf{P P}(\boldsymbol{\mu m})$ & $\mathbf{S P}(\boldsymbol{\mu m})$ & $\operatorname{MES}(\boldsymbol{\mu m})$ & $\operatorname{LIB}(\boldsymbol{\mu m})$ \\
\hline Dense Cerrado & $15.61 \mathrm{c}$ & $12.99 \mathrm{~b}$ & $92.42 \mathrm{a}$ & $38.79 \mathrm{~b}$ & $131.21 \mathrm{~b}$ & $159.82 \mathrm{~b}$ \\
Typical Cerrado & $17.17 \mathrm{~b}$ & $12.62 \mathrm{~b}$ & $78.35 \mathrm{~b}$ & $53.10 \mathrm{c}$ & $131.45 \mathrm{~b}$ & $161.24 \mathrm{~b}$ \\
Sparse Cerrado & $23.08 \mathrm{a}$ & $17.77 \mathrm{a}$ & $87.68 \mathrm{a}$ & $60.78 \mathrm{a}$ & $148.46 \mathrm{a}$ & $189.31 \mathrm{a}$ \\
\hline
\end{tabular}

*averages with the same letter in the columns do not differ from each other according to Dunn's test at 5\% significance level. ADE: adaxial epidermis; ABE: abaxial epidermis; PP: palisade parenchyma; SP: spongy parenchyma; MES: mesophyll and LIB: limbo.

\section{Discussion}

The thick cuticle found in the current study is a feature of xeromorphic plants found in savanna environments with marked seasonal variation (Dickinson 2000). The presence of more than one layer of columnar-shaped parenchyma tissues is a common feature of leaves exposed to large amounts of sunlight, probably due to the extensive exposure of these leaflets to the sun. Besides facilitating the penetration and distribution of light into the mesophyll, this feature also facilitates gas exchange among the cells (Dickison 2000; Vogelmann et al. 1996). 

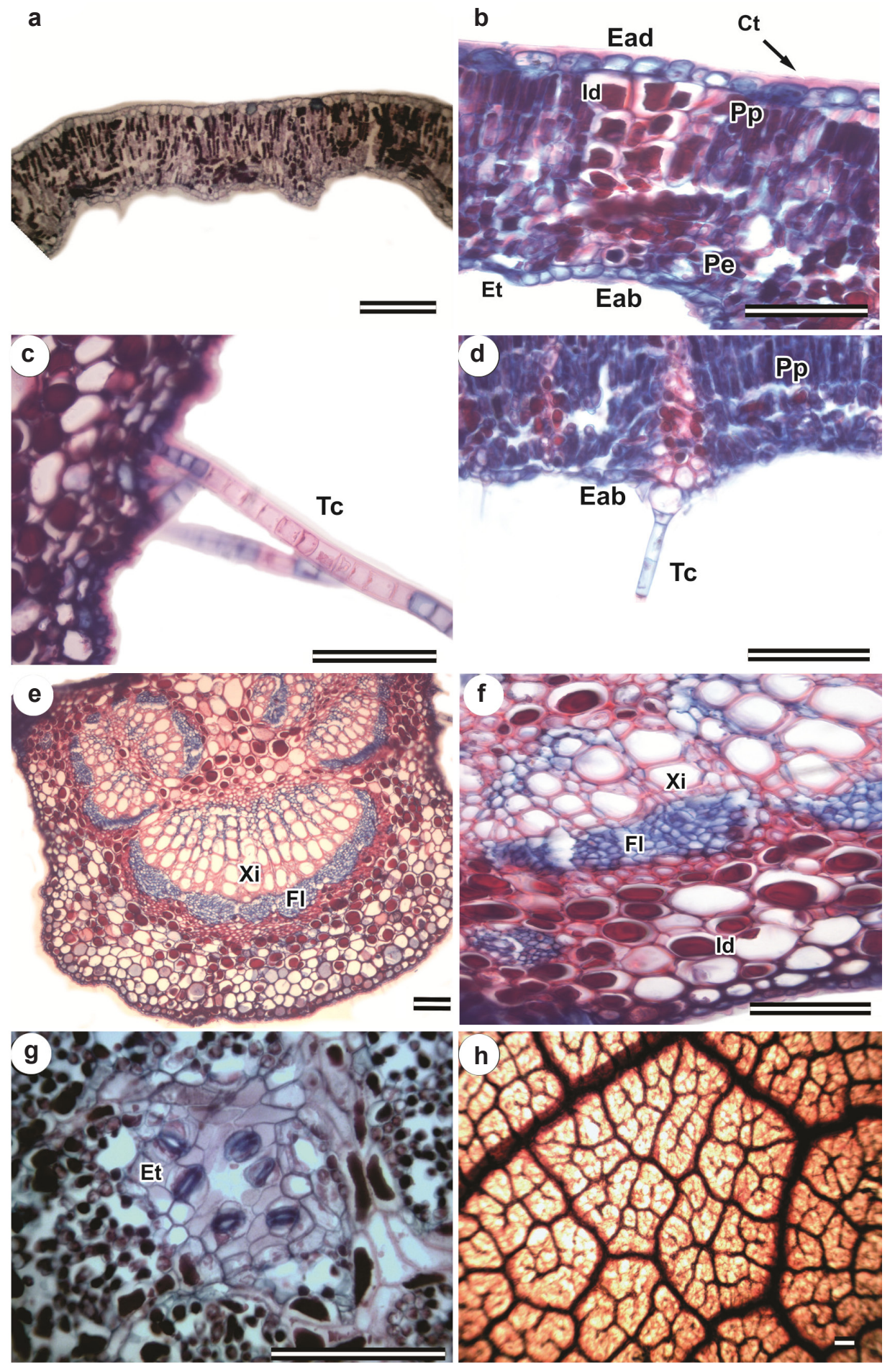

Figure 2 - Caryocar brasiliense leaflet structure. a. General aspect of the mesophyll in cross section. b. Detail of the mesophyll in cross section. c. Detail of non-glandular trichomes, main nervure and abaxial surface epidermis in cross section. d. Detail of non-glandular trichomes, main nervure in cross section. e. Overview of the main nervure in cross section. f. Detail of the main nervure in cross section. g. Overview of stomata in paradermal section. h. Leaf venation structure, diafanization. Eab, adaxial surface epidermis; Ead, abaxial surface epidermis; Pp, palisade parenchyma; Pe, spongy parenchyma; Ct, cuticle; Tc, trichome; Id, idioblast; Xi, xylem; PI, phloem; Et, stoma. Bar $=100 \mu \mathrm{m}$. 
Caryocar brasiliense presents dense trichomes along the main vein and in the abaxial surface epidermis of its leaflets. Such trichomes may be related to a water-conservation strategy in plant leaves occurring in heterogeneous environments, since trichomes help reflecting solar rays (Boeger et al. 2008). Hence, the importance of this structure to $C$. brasiliense is remarkable, because the current study was performed in heterogeneous environments, such as the three different studied Cerrado vegetation-types.

Some of the other anatomical features found in the current study, such as the presence of uniestratified and arched epidermis with revolute margin, abundant multicellular non-glandular trichomes, thick cuticle on both sides of the epidermis and branched vascular endings were consistent with those found by Castro et al. (2012) and Metcalfe \& Chalk (1965).

Higher values were found in the thickness of the adaxial and abaxial surface epidermis (ADE and $\mathrm{ABE}$ ), thickness of the spongy parenchyma (SP) and thickness of the mesophyll (MES) and limb (LIB) in the leaflets of plants collected from sparse cerrado vegetation-type. The presence of thicker epidermis and mesophyll in leaflets of plants from such vegetation-type may have been influenced by some environmental factors, such as the low nutrient content in the soil, the frequency of fire in the area, in addition to high light intensity and high temperatures, can also lead to pronounced loss of water. According to Boeger \& Gluzezak (2006) and Boeger et al. (2007), some plants are likely to make some morphological adjustments that enable them to maintain their physiological processes, thus ensuring successful occupation in different habitats.

The soil in the studied areas was poor in nutrients, with acid $\mathrm{pH}$ and high aluminum concentration. The Dense cerrado vegetation-type showed slightly higher fertility when compared with that found in the other areas. The highest temperatures occurred during the months the collections were performed in, and the rainfall shortage lead to the water deficit found in individuals from the three studied vegetation-types.

Water deficit and high temperatures are amongst the environmental factors that mostly contribute to stress in plants. Plants with the ability to change cell-shape or to increase the cell-wall thickness present better adaptive responses to environmental factors (Dickison 2000).

Sparse cerrado vegetation-type presents vegetation with less plants distributed over a larger area. This causes $C$. brasiliense leaves to be more exposed to sunlight when compared with other vegetation-types, and may, in turn, cause increased production of cell layers and, consequently, a greater thickening of the mesophyll as a response. Rôças et al. (1997) also found greater mesophyll spacing in leaves of Alchornea triplinervia related to high light intensity environments.

The pressure caused by fires on sparse cerrado vegetation-type is another factor that may have contributed to the greatest thickening of cell tissues in leaflets of plants from this vegetation type. Unlike the others, this area has undergone the action of fire twice, one in 2010 and another in 2011. Fire is one of the factors that mostly influence the dynamics of savannas by altering their floristic composition, the ratio between woody and herbaceous plants and the phytophysiognomic features of Cerrado vegetation. It also has negative effects on woody plants (Sharpe 1992; Moreira 2000).

As for the thickness of palisade parenchyma (PP), the higher averages were found in the dense cerrado vegetation-type. The increased thickness of the parenchyma consequently increases leaf thickness (Boeger \& Gluzezak 2006), as well as the presence of thicker palisade parenchyma facilitates the penetration of light through the mesophyll, thus improving photosynthetic rates (Boeger et al. 2008). However, as previously mentioned, the greater thickness of the limb (LIB) and mesophyll (MES) was found in the sparse cerrado vegetation-type.

As Dense cerrado has taller plants with higher density of trees and smaller spacing between them, even with the occurrence of high incidence of light, competition for light is more intense in this vegetation-type (Ribeiro \& Walter 2008). Thus, the increased thickness of the palisade parenchyma in this vegetation-type can be considered as a response to the better adjustment of $C$. brasiliense photosynthetic rates in dense cerrado, also taking under consideration the influence of environmental conditions.

The presence of arched abaxial surface epidermis in C. brasiliense leaflets was another strategy evidenced in all studied areas. This rugosity may change the airflow in the boundary layer. Leaves generally change this boundary layer to increase the scattering of light and heat, a common feature in leaves that have greater exposure to the sun and wind, and to help gas exchange, since, to some extent, some plants anatomical features can be modified according to the environment they are inserted in (Cutler et al. 2011). 
According to Metcalfe \& Chalk (1965), plants from Caryocaraceae family show vascular system with the main nervure closely related to the size of the nervures. Thus, the presence of the sheath, which extends into the epidermis around the accessory bundles, corroborates a possible response to improve water transport by mesophyll while providing support and protection to vascular tissues (Castro \& Menezes 1995; Van Der Merwe et al. 1994). Proença \& Sajo (2004) also found such feature in the smaller caliber vascular bundles of Aechmea species (Bromeliaceae).

In the current study, $C$. brasiliense presented many trichomes, thick cuticle and increased layers of parenchyma cells. These features supposedly help the species to overcome the environmental heterogeneity by means of phenotypic plasticity, a strategy that allows plants explore new niches and resources, thereby expanding their distribution into more heterogeneous environments (Cardoso \& Lomônaco 2003).

Therefore, the studied C. brasiliense plants showed many morphometric differences in their tissues, probably influenced by the particular features of each vegetation-type. The differences anatomical were punctual, although essential to the plants survival under the different environmental conditions found in Cerrado vegetation-types. Thus, it can be suggested that the studied plants are well adapted to their habitat and to the influence of environmental factors.

\section{Acknowledgment}

The authors would like to thank Capes for the scholarship and the Federal University of Tocantins for logistic support, and Daniela Zappi for the English review.

\section{References}

Aguiar, T.V.; Sant anna- Santos, B.F.; Azevedo, A.A. \& Ferreira, R.S. 2007. Anat Quant: Software de Análises Quantitativas para Estudos em Anatomia Vegetal. Planta Daninha 25: 649-659.

Almeida, S.P.; Proença, C.E.B.; Sano, S.M.\& Ribeiro, J.F. 1998. Cerrado: espécies vegetais úteis. Embrapa-CPAC, Planaltina. 464p.

Almeida, S.P. \& Silva, J.A. 1994. Piqui e buriti: importância alimentar para a população dos Cerrados. Embrapa-CPAC, Planaltina. 38p.

Araujo, F.D. 1995. A Rewiew of Caryocar brasiliense (Caryocaraceae) an economically valuable species of the Central Brazilian Cerrados. Economic Botany 49: 40-98.

Barradas, M.M. 1972. Informações sobre floração, frutificação e dispersão do piqui Caryocar brasiliense Camb. (Caryocaraceae). Ciência \& Cultura 24: 1063-1068.

Bieras, A.C. \& Sajo, M.G. 2004. Anatomia foliar de Erythroxylum P. Browne (Erythroxylaceae) do Cerrado do estado de São Paulo, Brasil. Acta Botânica. Brasilica18: 601-612.

Bersier, J.D. \& Bocquet, G. 1960. Les methods d' éclaircissement en vascularisation et en morphogénie végetales comparíes. Archives des Sciences 13: 555-566.

Boeger, M.R.T. \& Gluzezak, R.M. 2006. Adaptações estruturais de sete espécies de plantas para as condições ambientais da área de dunas de Santa Catarina, Brasil. IHeringia 61: 73-82.

Boeger, M.R.T.; Cavichiolo, L.E.; Pil, M.W.\& Labiak, P.H. 2007. Variabilidade fenotípica de Rumohra adiantiformis (G. Forst) Ching ( Dryopteridaceae). Hoehnea 34: 553-561.

Boeger, M.R.T.; Gluzezak, R.M.; Pil, M.W.; Goldenberg, R.\& Medri, M. 2008. Variabilidade morfológica foliar de Miconia sellowiana (D.C) Naudin (Melastomataceae) em diferentes fitofisionomias no Estado do Paraná. Revista Brasileira de Botânica 31: 443-452.

Castro, A.C.R.; Leite, G.L.D.; Oliveira, D.C. \& Isaias, R.M.S. 2012. Morphological patterns of a Hymenopteran Gall on the leaflets of Caryocar brasiliense Camb. (Caryocaraceae). American Journal of Plant Sciences 3: 921-929.

Castro, N.M. \& Menezes, N.L. 1995. Aspectos da anatomia foliar de algumas espécies de Paepalanthus Kunth, Eriocaulaceae da Serra do Cipó (Minas Gerais). Acta Botanica Brasilica 9: 213-229.

Cardoso, G.L. \& Lomônaco, C. 2003. Variações fenotípicas e potencial plástico de Eugenia calycina Cambess. (Myrtaceae) em uma área de transição Cerrado-Vereda. Revista Brasileira de Botânica 26: 131-140.

Carvalho, P.E.R. 2009. Pequizeiro: Caryocar brasiliense. Comunicado Técnico 230-Embrapa, Colombo. 10p.

Cutler, D.F.; Botha,T.\& Stevenson, D.W. 2011. Anatomia Vegetal- Uma Abordagem aplicada. Artmed, Porto Alegre. 304p.

Dickison, W.C. 2000. Integrative Plant Anatomy. Academic Press, Harcourt. 533p.

Franco, A.C. 2005. Biodiversidade de forma e função: implicações ecofisiológicas de utilização de água e luz em plantas lenhosas do Cerrado. In: Scariot, A.; Sousa-Silva, J.C.\& Felfili, J.M. (eds.). Cerrado: Ecologia, Biodiversidade e Conservação. Cap.10. Ministério do Meio Ambiente, Brasília. Pp. 181-196.

Felfili, J.M. \& Silva-Júnior, M.C. 2005. Diversidade alfa e beta no Cerrado sensu strictu, Distrito Federal, Goiás, 
Minas Gerais e Bahia. In: Scariot, A.; Sousa-Silva, J.C.\& Felfili, J.M. Cerrado: Ecologia, Biodiversidade e Conservação. Cap.7. Ministério do Meio Ambiente, Brasília. Pp. 143-154.

Gonçalves, E.G. \& Lorenzi, H. 2007. Morfologia Vegetal: Organografia e dicionário ilustrado de morfologia das plantas vasculares. Instituto Plantarum, São Paulo. 416p.

Johansen, D.A. 1940. Plant Microtechniche. Mc Graw Hill, New York. 523p.

Lorenzi, H. \& Matos, F.J.A. 2008. Plantas Medicinais do Brasil: nativas e exóticas. Instituto Plantarum, Nova Odessa SP. Vol. 2. Pp 205-206.

Lusa, M.G. \& Bona, C. 2011. Caracterização morfoanatômica e histoquímica de Cuphea carthagenensis (Jacq.) J.f. Macbr. (Lythraceae). Acta Botânica Brasilica 25: 517-527.

Metcalfe, C.R. \& Chalk, L. 1965. Anatomy of the dicotiledons, leaves, steam and wood in relations to taxonomy whit notes on economic uses. Clarendon Press. 560p.

Moreira, A.G. 2000. Effects of fire protection on savanna structure in Central Brazil. Journal of Biogeography 27: 1021-1029.

Prance, G.T. \& Silva, M.F. 2006. Flora da reserva Ducke, Amazonas, Brasil: Caryocaraceae. Rodriguésia 57:155-157.

Proença, S.L. \& Sajo, M.G. 2004. Estrutura foliar de espécies de Aechmea Ruiz \& Pav. (Bromeliaceae) do Estado de São Paulo, Brasil. Acta Botânica Brasilica18 :319-331.
Reatto, A. \& Martins, E.S. 2005. Classes de solo em relação aos controles da paisagem do bioma Cerrado. In: Scariot, A.; Sousa-Silva, J.C.\& Felfili, J.M. Cerrado: Ecologia, Biodiversidade e Conservação. Ministério do Meio Ambiente, Brasília. Cap1. Pp 49-59.

Ribeiro, J.F. \& Walter, B.M. 2008. As principais fitofisionomias do bioma Cerrado. In: Sano, S.M.; Almeida, S.P.\& Ribeiro, J.F. Cerrado: Ecologia e Flora. Embrapa Informação Tecnológica, Brasília. vol. 1. Pp 151-199.

Rôças, G.; Barros, C.F.\& Scarano, F.R. 1997. Leaf anatomy plasticity of Alchornea triplinervia (Euphorbiaceae) under distinct light regimes in a Brazilian Montane Atlantic rain forest. Trees 11: 469-473.

Rocha- Filho, L.C. \& Lomônaco, C. 2006. Variações fenotípicas em sub populações de Davilla elliptica A. St. - Hil. (Dilleniaceae) e Byrsonima intermédia A. Juss. (Malpighiaceae) em uma área de transição Cerrado- Vereda. Acta Botânica. Brasilica 20: 719-725.

Santos- Sant`Anna, B.F.; Duque-Brasil, R.; Azevedo, A.A.; Silveira, A.S.; Araujo, J.M.\& Aguiar, R. 2007. Utilização de parâmetros morfoanatômicos na análise da fitotoxidez do flúor em folhas de Magnolia ovata (A. St. - Hil) Spreng. (Magnoliaceae). Revista Árvore 31: 761-771.

Sharpe, C. 1992. Dynamics of savanna ecosystems. Journal of Vegetation Science 3: 293-300.

Vogelmann, T.C.; Nishio, J.N. \& Smith, W.K. 1996. Leaves and light capture: light propagation and gradients of carbon fixation within leaves. Trends in Plant Science1: 65-70. 